\title{
A Review of the Relationship between Wine Consumption and Type 2 Diabetes Mellitus
}

\author{
Creina S. Stockley
}

\author{
The Australian Wine Research Institute, PO Box 197, Glen Osmond SA 5064, Australia
}

\begin{abstract}
The potential health benefits of moderate alcohol consumption are not limited to a reduced risk of cardiovascular disease but are also observed for type 2 diabetes mellitus. The relationship appears to be J-shaped where moderate alcohol consumption reduces the risk of developing type 2 diabetes mellitus in both men and women, irrespective of age, and in those with a low and a high body mass index. The optimal amount of wine appears to be approximately two drinks per day, where a standard drink in Australia is considered to be $10 \mathrm{~g}$ alcohol. Given that the incidence of diabetes is projected to approximately double in the next 15 years, simple dietary supplementation to a healthy diet and lifestyle to reduce the risk will become increasingly important. This paper reviews the association between wine specifically and type 2 diabetes mellitus, and discusses biological mechanisms related to the association.
\end{abstract}

Keywords: Wine, alcohol, resveratrol, diabetes phenolic compound, consumption.

\section{INTRODUCTION}

The prevalence of diabetes mellitus is escalating worldwide. Its incidence is projected to increase from approximately 1.7 million now to 3.5 million in 2033 in Australia as an estimated 275 Australians develop type 2 diabetes mellitus per day [1]. The disease mainly develops in adults after the age of 45 years.

Type 2 diabetes mellitus, which accounts for more than $85 \%$ of all incidences of diabetes mellitus, is a disorder characterised by resistance to the effects of circulating insulin. This disorder leads to a substantial increase in risk of cardiovascular disease, which is the major cause of mortality, accounting for up to $80 \%$ of all deaths in individuals with type 2 diabetes mellitus [24]. The age-adjusted relative risk of death due to cardiovascular disease is approximately three-fold higher than in the general population. Approximately 30 to $60 \%$ of diabetics have hypertension $[5,6]$. In addition, individuals with type 2 diabetes mellitus have coexistent lipid disorders characterised by increased blood triglycerides and reduced HDL-cholesterol, as well as haemostatic and fibrinolytic abnormalities [4] similar to individuals with, or at risk of, cardiovascular disease.

In addition to those with the disease, an estimated 2 million Australians are pre-diabetic, which is defined as having an abnormally high blood glucose level (hyperglycaemia). Australians with pre-diabetes are at higher risk of developing type 2 diabetes in the following five years [7]. There is strong evidence from

*Address correspondence to this author at the Australian Wine Research Institute, PO Box 197, Glen Osmond SA 5064, Australia; Tel: +61 883136600; Fax: +61 883136601; E-mail: creina.stockley@awri.com.au

E-ISSN: 1929-5634/15 international, randomised controlled trials that type 2 diabetes mellitus can be prevented in many of these high-risk individuals through weight loss, and changes to diet and exercise [8-11].

\section{ALCOHOLIC BEVERAGES AND DIABETES}

Apart from obesity and physical inactivity there are few well-established modifiable risk factors for type 2 diabetes mellitus. Recent evidence suggests, however, that alcohol consumption may be a potentially modifiable risk factor for type 2 diabetes mellitus. A J-shaped relationship has been observed between level of alcohol consumption and risk of developing diabetes in both men and women [12-21], where regular moderate alcohol consumption is associated with a $30-40 \%$ reduced risk of type 2 diabetes [22-26]. This is shown by Lim et al. (2012) in Figure 1 [107].

The most recent meta-analysis of 20 cohort studies by Baliunas et al. (2009) [25] suggested that for women, the risk of developing type 2 diabetes mellitus was observed to be most reduced at $24 \mathrm{~g}$ alcohol/day, with a risk reduction of $40 \%$ compared with lifetime abstainers. Alcohol consumption remained protective until approximately $50 \mathrm{~g} /$ day. For men, the protective effect of alcohol consumption was greatest at $22 \mathrm{~g} /$ day, with the risk of diabetes being 0.87 times that of lifetime abstainers, and remained protective until consumption of $60 \mathrm{~g} /$ day. Therefore, for both women and men, the protective effect of alcohol consumption on incident type 2 diabetes mellitus was greatest with the consumption of approximately two drinks/day. Similarly, for both men and women, higher amounts of consumption (above $50 \mathrm{~g} /$ day for women and $60 \mathrm{~g} /$ day for men) were no longer protective and increased the risk for diabetes. Indeed, as in the general population, 


\section{Diabetes mellitus}

Men

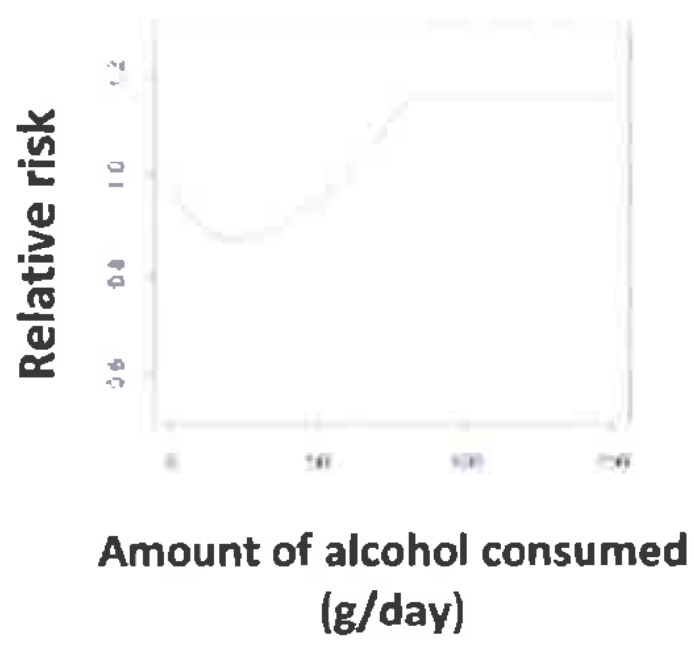

Women

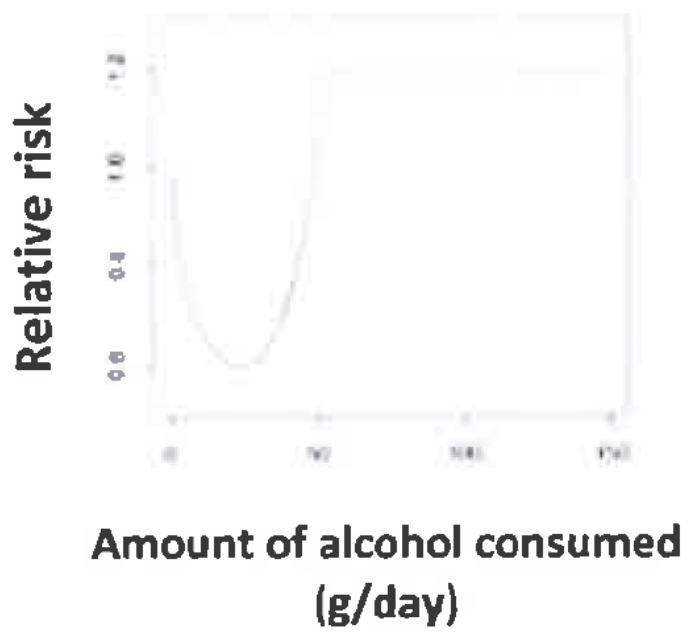

Figure 1: The relationship between the relative risk of developing diabetes and average daily alcohol consumption compared with lifetime abstinence (Adapted and extracted from Lim et al. 2012) [107].

there is also a decrease in cardiovascular risk with moderate alcohol consumption in type 2 diabetics $[16,27,28]$. These 20 cohort studies did not necessarily differentiate, however, between beer, wine and spirits and an association with type 2 diabetes mellitus.

\section{METHOD}

This review paper discusses the available published literature on the relationships between diabetes and the consumption of alcoholic beverages, and specifically wine, through a systematic search of the electronic database PUBMED from January 1980 up to December 2014. The published literature included meta-analyses, case-control and prospective cohort studies, relevant reviews, experimental and clinical studies, and references of identified papers, but excluded letters, editorials, conference abstracts and commentaries. No language restrictions were applied. Articles were included if they fulfilled the following criteria: (a) epidemiological studies with a case-cohort or cohort study design; (b) studies on the association of diabetes incidence with wine consumption or with wine, beer and spirit consumption; (c) studies presenting the odds ratio, risk ratio, or hazard ratio estimates with the corresponding 95\% confidence intervals (Cls); and (d) never and/or occasional (non/occasional) drinkers as the reference category or available data for non/occasional drinkers. Also articles on wine products were included but not those on wine components except where mechanistic material was provided.

\section{RESULTS}

\section{Wine and Diabetes}

A review of the literature provided 22 individual studies post 2000 which have specifically assessed the effect of wine consumption on the risk of type 2 diabetes (Table 1). Of these, 14 assessed the risk of developing type 2 diabetes mellitus and a further six assessed the risk of micro-vascular and other complications associated with type 2 diabetes mellitus as well as all-cause mortality. Population groups from at least nine different countries were included in the studies.

All studies consistently observed a decreased risk of developing type 2 diabetes mellitus with moderate wine consumption in both men [14,15,29] and women [21,30-32], although in some studies a decreased risk was observed at different amounts of wine consumption [33]. The optimal amount of wine appeared to be approximately two drinks/day, where a standard drink in Australia is considered to be $10 \mathrm{~g}$ alcohol [34]. Wine consumed with food, and especially as an integral component of Mediterranean-type diet, was inversely associated with type 2 diabetes mellitus [35-37]. The inverse association was particularly observed for overweight and obese individuals at higher risk of developing the disease [32,33,35], in middle-aged individuals $[17,38]$ and in elderly individuals $[30,39]$. Above moderate amounts, the risk of developing type 2 diabetes mellitus generally 
Table 1: Individual Studies Assessing the Effect of Wine Consumption on Type 2 Diabetes Post 2000

\begin{tabular}{|c|c|c|c|c|c|c|}
\hline Study & $\begin{array}{l}\text { Study, country } \\
\text { and type }\end{array}$ & $\begin{array}{l}\text { Population } \\
\text { studied }\end{array}$ & $\begin{array}{c}\text { Reduced risk of } \\
\text { Type } 2 \text { diabetes } \\
\text { or other related } \\
\text { effects } \\
\text { observed for } \\
\text { wine }\end{array}$ & $\begin{array}{c}\text { Amount of } \\
\text { wine } \\
\text { associated } \\
\text { with reduced } \\
\text { risk }\end{array}$ & $\begin{array}{c}\text { Beverage } \\
\text { differentiation } \\
\text { observed }\end{array}$ & $\begin{array}{c}\text { Gender } \\
\text { differentiation } \\
\text { observed }\end{array}$ \\
\hline $\begin{array}{c}\text { Marques-Vidal et } \\
\text { al. } 2015 \text { [108] }\end{array}$ & $\begin{array}{c}\text { CoLaus Study } \\
\text { Switzerland } \\
\text { cohort }\end{array}$ & $\begin{array}{c}4765 \text { subjects } \\
\text { followed for an } \\
\text { average of } 5.5 \mathrm{yr}\end{array}$ & yes & $\begin{array}{c}14-27 \\
\text { drinks/week }\end{array}$ & no & no \\
\hline $\begin{array}{c}\text { Blomster et al. } \\
2014 \text { [49] }\end{array}$ & $\begin{array}{c}\text { ADVANCE Study } \\
20 \text { countries } \\
\text { cohort }\end{array}$ & $\begin{array}{l}\text { 11,140 T2DM } \\
\text { subjects }\end{array}$ & $\begin{array}{l}\text { Yes for } \\
\text { cardiovascular } \\
\text { events and all- } \\
\text { cause mortality }\end{array}$ & Moderate & Wine >beer, spirits & $\mathrm{n} / \mathrm{a}$ \\
\hline $\begin{array}{l}\text { Fagherazzi et al. } \\
2014 \text { [32] }\end{array}$ & $\begin{array}{c}\text { E3N-EPIC Study } \\
\text { France } \\
\text { cohort }\end{array}$ & $\begin{array}{l}66,485 \text { female } \\
\text { subjects }\end{array}$ & $\begin{array}{l}\text { Yes in } \\
\text { overweight } \\
\text { women }\end{array}$ & $\geq 2$ drinks/day & $\mathrm{n} / \mathrm{a}$ & $\mathrm{n} / \mathrm{a}$ \\
\hline $\begin{array}{c}\text { Koloverou et al. } \\
2014 \text { [37] }\end{array}$ & $\begin{array}{l}\text { ATTICA Study } \\
\text { Greece } \\
\text { cohort }\end{array}$ & $\begin{array}{l}1514 \text { men and } \\
1528 \text { women } \\
\text { followed for } 10 \mathrm{yr}\end{array}$ & $\begin{array}{c}\text { Yes } \\
\downarrow \downarrow \text { for } \\
\text { Mediterranean } \\
\text { diet and no } \\
\text { metabolic } \\
\text { syndrome }\end{array}$ & 1 drink/day & $\begin{array}{c}\text { wine }=\text { beer }> \\
\text { spirits }\end{array}$ & no \\
\hline $\begin{array}{l}\text { Rojo-Martinez et al. } \\
2014 \text { [50] }\end{array}$ & $\begin{array}{c}\text { Study } \\
\text { Spain } \\
\text { case-control }\end{array}$ & $\begin{array}{l}1031 \text { T2DM } \\
\text { subjects }\end{array}$ & $\begin{array}{l}\text { Yes for serum } \\
\text { sCD163 levels } \\
\text { associated with } \\
\text { insulin resistance }\end{array}$ & & $\mathrm{n} / \mathrm{a}$ & no \\
\hline $\begin{array}{c}\text { Bauer et al. } 2013 \\
\text { [35] }\end{array}$ & $\begin{array}{l}\text { EPIC-NL Study } \\
\text { The Netherlands } \\
\text { cohort }\end{array}$ & $\begin{array}{l}20,835 \text { subjects } \\
\text { with a BMl } \geq 25 \\
\mathrm{~kg} / \mathrm{m}^{2}\end{array}$ & $\begin{array}{l}\text { Not associated } \\
\text { with T2DM as } \\
\text { part of } \\
\text { Mediterranean- } \\
\text { type diet }\end{array}$ & & $\mathrm{n} / \mathrm{a}$ & no \\
\hline $\begin{array}{c}\text { Fernemark et al. } \\
2013 \text { [36] }\end{array}$ & $\begin{array}{l}\text { Peru } \\
\text { In vivo }\end{array}$ & $\begin{array}{l}21 \text { T2DM } \\
\text { subjects }\end{array}$ & $\begin{array}{c}\text { Yes for } \\
\text { postprandial } \\
\text { glucose } \\
\text { elevations for } \\
\text { Mediterranean- } \\
\text { type diet }\end{array}$ & $\begin{array}{l}150-200 \\
\mathrm{~mL} / \text { day }\end{array}$ & $\mathrm{n} / \mathrm{a}$ & no \\
\hline $\begin{array}{c}\text { Beulens et al. } 2012 \\
\text { [33] }\end{array}$ & $\begin{array}{l}\text { EPIC-InterAct } \\
\text { Study } \\
8 \text { countries } \\
\text { cohort }\end{array}$ & 16,154 subjects & $\begin{array}{c}\text { Yes } \\
\downarrow \downarrow \text { for } \\
\text { overweight } \\
\text { subjects }\end{array}$ & $\begin{array}{l}\text { 24.1-96 g/day } \\
\text { (men) } \\
6.1-12 \mathrm{~g} / \text { day } \\
\text { (women) }\end{array}$ & $\begin{array}{c}\text { Wine + fortified } \\
\text { wine > beer, cider, } \\
\text { spirits }\end{array}$ & $\begin{array}{l}\text { Women }>\text { men } \\
0.5-1 \text { drink/day } \\
\downarrow \text { risk by } 20 \% \\
\text { in women } \\
\text { compared to } \\
13 \% \text { in men }\end{array}$ \\
\hline $\begin{array}{l}\text { Rasouli et al. } 2012 \\
\text { [29] }\end{array}$ & $\begin{array}{l}\text { HUNT Study } \\
\text { Norway } \\
\text { cohort }\end{array}$ & $\begin{array}{c}90,269 \text { subjects } \\
\text { followed for } 11 \text { or } \\
22 \mathrm{yr}\end{array}$ & $\begin{array}{c}\text { Yes for both } \\
\text { T2DM and auto- } \\
\text { immune diabetes } \\
\text { in men }\end{array}$ & $\begin{array}{c}\text { 10-15 g/day } \\
\text { binge and high } \\
\text { alcohol } \\
\text { consumption } \\
\text { did not increase } \\
\text { risk }\end{array}$ & $\begin{array}{l}\text { wine >> beer, } \\
\text { cider, spirits }\end{array}$ & Mens women \\
\hline $\begin{array}{c}\text { Beulens et al. } 2010 \\
\text { [48] }\end{array}$ & $\begin{array}{l}\text { SMART disease } \\
\text { study } \\
\text { The Netherlands }\end{array}$ & $\begin{array}{c}5447 \text { subjects } \\
\text { with DM or } \\
\text { vascular disease } \\
\text { followed for } 4.7 \\
\text { yr }\end{array}$ & $\begin{array}{l}\text { Yes for stroke, } \\
\text { amputations, } \\
\text { vascular all- } \\
\text { cause mortality }\end{array}$ & 1-2 drinks/day & Wine $>$ beer, spirits & no \\
\hline $\begin{array}{c}\text { Beulens et al. } 2008 \\
\text { [47] }\end{array}$ & $\begin{array}{l}\text { EURODIAB study } \\
\text { The Netherlands }\end{array}$ & $\begin{array}{l}\text { 3,250 T2DM } \\
\text { subjects }\end{array}$ & $\begin{array}{c}\text { Yes for all } \\
\text { microvascular } \\
\text { complications }\end{array}$ & Moderate & Wine >beer, spirits & no \\
\hline $\begin{array}{c}\text { Athyros et al. } 2007 \\
{[106]}\end{array}$ & $\begin{array}{l}\text { Greece } \\
\text { cohort }\end{array}$ & 4153 subjects & yes & Moderate & Wine $>$ beers $>$ spirits & no \\
\hline
\end{tabular}




\begin{tabular}{|c|c|c|c|c|c|c|}
\hline Study & $\begin{array}{l}\text { Study, country } \\
\text { and type }\end{array}$ & $\begin{array}{l}\text { Population } \\
\text { studied }\end{array}$ & $\begin{array}{c}\text { Reduced risk of } \\
\text { Type } 2 \text { diabetes } \\
\text { or other related } \\
\text { effects } \\
\text { observed for } \\
\text { wine }\end{array}$ & $\begin{array}{c}\text { Amount of } \\
\text { wine } \\
\text { associated } \\
\text { with reduced } \\
\text { risk }\end{array}$ & $\begin{array}{c}\text { Beverage } \\
\text { differentiation } \\
\text { observed }\end{array}$ & $\begin{array}{c}\text { Gender } \\
\text { differentiation } \\
\text { observed }\end{array}$ \\
\hline $\begin{array}{c}\text { Djousse et al. } 2007 \\
\text { [39] }\end{array}$ & $\begin{array}{c}\text { Cardiovascular } \\
\text { Health Study } \\
\text { USA } \\
\text { cohort }\end{array}$ & $\begin{array}{c}4655 \text { elderly } \\
\text { subjects followed } \\
\text { for average of } \\
6.3 \mathrm{yr}\end{array}$ & Yes & $\begin{array}{l}\text { Light - } \\
\text { moderate }\end{array}$ & no & no \\
\hline $\begin{array}{c}\text { Hodge et al. } 2006 \\
{[38]}\end{array}$ & $\begin{array}{c}\text { Melbourne } \\
\text { Collaborative } \\
\text { Cohort Study } \\
\text { Australia } \\
\text { Prospective } \\
\text { cohort }\end{array}$ & $\begin{array}{l}36,527 \text { subjects } \\
\text { followed for } 4 \mathrm{yr}\end{array}$ & Yes & $\begin{array}{l}\text { Light - } \\
\text { moderate }\end{array}$ & Wine >>beer, spirits & no \\
\hline $\begin{array}{c}\text { Marfella et al. } 2006 \\
{[46]}\end{array}$ & $\begin{array}{c}\text { USA } \\
\text { Intervention }\end{array}$ & $\begin{array}{c}115 \text { T2DM } \\
\text { subjects post MI }\end{array}$ & $\begin{array}{c}\text { Yes for } \\
\downarrow \text { oxidative } \\
\text { stress, pro- } \\
\text { inflammatory } \\
\text { cytokines, and } \\
\text { cardiac function } \\
\text { post Ml }\end{array}$ & $\begin{array}{c}\text { Regular, } \\
\text { moderate with } \\
\text { meals }\end{array}$ & $\mathrm{n} / \mathrm{a}$ & no \\
\hline $\begin{array}{c}\text { Beulens et al. } 2005 \\
{[30]}\end{array}$ & $\begin{array}{l}\text { Dutch Prospect- } \\
\text { EPIC Study } \\
\text { The Netherlands } \\
\text { cohort }\end{array}$ & $\begin{array}{l}16,330 \text { elderly } \\
\text { female subjects } \\
\text { followed for } \\
\text { averages } 6.2 \mathrm{yr}\end{array}$ & Yes & Moderate & no & $\mathrm{n} / \mathrm{a}$ \\
\hline $\begin{array}{c}\text { Lapidus et al. } 2005 \\
\text { [31] }\end{array}$ & $\begin{array}{c}\text { Sweden } \\
\text { Longitudinal } \\
\text { population }\end{array}$ & $\begin{array}{c}1,462 \text { female } \\
\text { subjects followed } \\
\text { for } 32 \mathrm{yr}\end{array}$ & yes & Moderate & no & $\mathrm{n} / \mathrm{a}$ \\
\hline $\begin{array}{c}\text { Wannamethee et } \\
\text { al. } 2003 \text { [21] }\end{array}$ & $\begin{array}{c}\text { Nurses' Health } \\
\text { Study } \\
\text { USA } \\
\text { Prospective } \\
\text { cohort }\end{array}$ & $\begin{array}{c}109,690 \text { female } \\
\text { subjects followed } \\
\text { for } 10 \mathrm{yr}\end{array}$ & yes & $\begin{array}{l}\text { Light to } \\
\text { moderate }\end{array}$ & $\begin{array}{c}\text { Wine }=\text { beer }>\text { spirits } \\
>30 \text { g/day as spirits } \\
\uparrow \text { risk }\end{array}$ & $\mathrm{n} / \mathrm{a}$ \\
\hline Kao et al. 2001 [17] & $\begin{array}{l}\text { ARIC Study } \\
\text { USA } \\
\text { Prospective } \\
\text { cohort }\end{array}$ & $\begin{array}{c}12,261 \text { middle- } \\
\text { aged subjects } \\
\text { followed for 3-6 } \\
\text { yr }\end{array}$ & no & $\mathrm{n} / \mathrm{a}$ & $\begin{array}{c}\text { Spirits }>\text { wine }=\text { beer } \\
\text { for } \uparrow \text { risk at }>14 \\
\text { drinks/week }\end{array}$ & $\begin{array}{c}\text { Men>women } \\
\text { for } \uparrow \text { risk at > } \\
21 \\
\text { drinks/week }\end{array}$ \\
\hline $\begin{array}{c}\text { Ceriello et al. } 2001 \\
\text { [45] }\end{array}$ & $\begin{array}{c}\text { Italy } \\
\text { intervention }\end{array}$ & $\begin{array}{l}20 \text { T2DM } \\
\text { subjects }\end{array}$ & $\begin{array}{c}\text { Yes for } \downarrow \\
\text { postprandial LDL } \\
\text { cholesterol and } \\
\text { thrombotic } \\
\text { activation }\end{array}$ & Moderate & $\mathrm{n} / \mathrm{a}$ & no \\
\hline $\begin{array}{c}\text { Conigrave et al. } \\
2001 \text { [15] }\end{array}$ & $\begin{array}{c}\text { Health } \\
\text { Professionals } \\
\text { Follow-Up Study } \\
\text { USA } \\
\text { Prospective } \\
\text { cohort }\end{array}$ & $\begin{array}{c}46,892 \text { male } \\
\text { subjects followed } \\
\text { for } 12 \mathrm{yr}\end{array}$ & yes & $\begin{array}{c}\text { Regular } \\
\text { moderate }\end{array}$ & no & $\mathrm{n} / \mathrm{a}$ \\
\hline $\begin{array}{l}\text { Carlsson et al. } \\
2000 \text { [14] }\end{array}$ & $\begin{array}{c}\text { Stockholm } \\
\text { Diabetes } \\
\text { Prevention } \\
\text { Program Study } \\
\text { Sweden } \\
\text { Cross-sectional } \\
\text { population based }\end{array}$ & $\begin{array}{c}3,128 \text { male } \\
\text { subjects }\end{array}$ & no & $\mathrm{n} / \mathrm{a}$ & $\begin{array}{c}\text { Spirits =beer }>\text { wine } \\
\text { for } \uparrow \text { risk at }>12 \\
\text { drinks/week }\end{array}$ & $\mathrm{n} / \mathrm{a}$ \\
\hline
\end{tabular}


increased with wine consumption $[14,17,21]$ similar to the consumption of other alcoholic beverages, and likely related to a dose dependent elevation of blood glucose levels [40]. The increased risk with the heavy consumption of alcoholic beverages may also reflect increases in body weight and changes to the plasma concentration of certain fats such as triglycerides, as well as increases in blood pressure $[41,42]$.

Concerning the effect of wine on risk of prediabetes, a reduced risk of progressing from normal to impaired fasting glucose and impaired glucose tolerance and to type 2 diabetes mellitus was observed with light to moderate wine consumption in women, where high wine consumption increased the risk of abnormal glucose regulation in men $[43,44]$.

Micro-vascular and other complications of type 2 diabetes mellitus were also inversely associated with regular moderate wine consumption [24,29,36,45-50]. Beulens et al. (2010) [48], for example, suggested that one to two drinks/day as wine was associated with a reduced risk of vascular-related deaths such as from coronary heart disease, myocardial infarction and stroke as well as non-fatal events including amputations in diabetic individuals at high risk of cardiovascular disease compared to abstainers.

The literature also suggested that wine consumption may be more protective than beer and spirits for preventing type 2 diabetes mellitus [29,33,38,51], as well as the micro-vascular and other complications of type 2 diabetes mellitus [29,47-49].

Interestingly, Rasouli et al. (2012) [29] also observed that moderate wine consumption also decreased the risk of autoimmune diabetes. Other similar studies are shown Table 2. Autoimmune diabetes is caused by cellular-mediated autoimmune damage of the insulin-producing pancreatic $\beta$-cells and includes both Type 1 diabetics and those adults with latent onset autoimmune diabetes. The moderate consumption of alcoholic beverages such as wine has been previously associated with a reduced risk of other autoimmune diseases such as rheumatoid arthritis [51] and systemic lupus erythematous [52].

\section{Potential Mechanisms of Action}

The development of insulin resistance is key in the pathogenesis of type 2 diabetes, where cells fail to respond, or become resistant, to insulin. Accordingly, the protective effect of alcoholic beverages on the development of type 2 diabetes mellitus has been attributed to increasing insulin sensitivity [53-57], reduced postprandial glycaemic response $[58,59]$ and increasing the concentration of circulating adiponectin, which is an adipocyte hormone associated with increasing insulin sensitivity [57,60-64].

A J-shaped relationship has also been observed between insulin sensitivity and level of alcohol consumption, where the moderate consumption of alcohol has been observed to improve insulin sensitivity, possibly by reducing the concentration of free fatty acids in blood $[65,24]$. This has been found in observational studies as well as in randomised controlled trials $[13,54,60,66,67]$. Short-term moderate red wine consumption has also specifically been observed to improve insulin sensitivity in type 2 diabetic individuals [68].

In turn, the improved insulin sensitivity lowers the concentration of insulin [69], glucose and triglycerides in the blood, and increases that of HDL, while LDL particles become less dense, less adherent and less easily oxidised. Altogether, this reduces the risk of developing type 2 diabetes mellitus, as well as improving control of blood glucose and reducing the risk of cardiovascular disease [70,71]. Following the consumption of 120 to $240 \mathrm{~mL}$ wine daily for 30 days fasting serum insulin concentration was also lowered [72].

Furthermore, the pre-dinner consumption of a moderate amount of wine may reduce fasting plasma glucose concentrations [73], peak blood glucose concentrations or the overall postprandial glycaemic response to a subsequent carbohydrate-containing meal. In lean healthy individuals, Brand-Miller et al. (2007) [59] observed that wine produced the greatest reduction in the postprandial glucose response compared to beer and spirits, despite contributing less alcohol. This suggests that wine could contain substances other than alcohol that are physiologically relevant.

In addition, adiponectin appears to be an important link between alcohol consumption, insulin sensitivity, type 2 diabetes and atherosclerosis [74,47]. High concentrations of adiponectin have been associated with lower risk of type 2 diabetes [75,76] and adverse cardiovascular events [77], where moderate alcohol consumption has been shown to increase adiponectin concentrations in healthy individuals, obese males, and women with impaired glucose tolerance and type 2 
diabetes [60-62,78,79]. Adiponectin also has antiinflammatory properties [80].

More recently, another protective mechanism has been suggested for moderate alcohol consumption related to glycaemic load (GL). The GL of food estimates how much the food will increase an individual's blood glucose concentration after consuming it, and represents the interaction between the quantity and quality of carbohydrate. One unit of glycaemic load approximates the effect of consuming one gram of glucose [81]. There is a positive doseresponse relationship between $\mathrm{GL}$ and the incidence of type 2 diabetes mellitus [82]. As alcohol metabolises differently to carbohydrates, it was proposed that the consumption of alcohol with food might attenuate the adverse effects of high GL foods on the risk of type 2 diabetes mellitus by delaying the insulin glucose response. Alcohol consumption of at least $15 \mathrm{~g} /$ day was observed by Mekary et al. (2011) [83] to decrease the positive relationship between $\mathrm{GL}$ and the incidence of type 2 diabetes mellitus in healthy women. Moderate alcohol consumption may also modify the metabolism of carbohydrate by decreasing glycogenolysis [84], fat oxidation [85] and the hormonal response to hypoglycaemia [86].

\section{Risk of Vascular Complications}

Patients with diabetes mellitus have other risk factors for cardiovascular disease such as a decreased total antioxidant capacity of plasma and concomitant increased LDL oxidation post-prandially $[87,88]$. Ceriello et al. (2001) [45] observed, however, that the consumption of red wine with food in type 2 diabetic patients decreased LDL oxidation post-prandially [89]. Furthermore, the post-prandial hypoglycaemia experienced in diabetes mellitus, which activates coagulation [90], was decreased by the consumption of red wine. The consumption of red wine by fasting type 2 diabetic patients, however, did not decrease either LDL oxidation or coagulation. Landrault et al. (2001) [91] also investigated whether wine-derived phenolic compounds increased the total plasma antioxidant capacity in an insulin-deficient diabetic rat model, as well as affecting glycaemia or blood sugar concentration, the biomarker of diabetes. Following the medium-term administration of both phenolic-enriched white wine and de-alcoholised phenolic-enriched white wine, the total plasma antioxidant capacity of the diabetic rats was increased to the level of non-diabetic rats and the level of glycaemia reduced by 15 to $20 \%$. This suggests that moderate wine consumption may also attenuate the debilitating hyper- and hypoglycaemic symptoms of diabetes.

Increased inflammation via an increase in circulating pro-inflammatory cytokines has been observed in both diabetic and non-diabetic patients and to be involved in the pathogenesis of cardiovascular complications such as endothelial dysfunction after a myocardial infarction [92]. Wine-derived phenolic compounds have anti-inflammatory actions including inhibition of reactive oxygen species in neutrophils, monocytes and macrophages [93,94]. In subjects with diabetes, red wine consumption, taken with meals, significantly reduces oxidative stress and the circulating concentration of pro-inflammatory cytokines from lymphocytes and macrophages such as C-reactive protein, tissue necrosis factor-alpha and interleukin-6, as well as improving cardiac function after a myocardial infarction [46].

One of the most studied wine-derived phenolic compounds is resveratrol. A recent meta-analysis on clinical parameters where resveratol was used as an adjunct to pharmaceutical interventions with type 2 diabetes mellitus, suggested that resveratrol consumption consistently increased the concentration of glycosylated haemoglobin (HbA1c) which is associated with a decreased risk of multiple complications and risk of death in diabetics [94]. It also decreased serum creatinine concentrations which are associated with kidney function. Increased serum creatinine concentrations (as well as $\mathrm{HbAIC}$ ) are a biomarker for kidney dysfunction and associated with a risk of nephropathy and cardiovascular disease [95,96]. In addition, resveratrol appeared to reduce systolic blood pressure which is also associated with risk of nephropathy and cardiovascular disease [97]. These data need to be considered cautiously, however, as the resveratrol was consumed in the studies was in higher amounts than that observed naturally in wine.

\section{CONCLUSIONS}

As acknowledged by the World Health Organization (WHO) in 2014, regular moderate wine consumption is causally linked to reduced risk of type 2 diabetes [98]. This has been observed for both genders and for individuals with a low or high body mass index. Conversely, heavy consumption appears to increase the risk of type 2 diabetes mellitus, although sample sizes generally have been too small to draw firm conclusions. 
Table 2: Studies Involving Type 1 Diabetes

\begin{tabular}{|c|c|c|c|c|c|c|}
\hline Study & Type of study & $\begin{array}{l}\text { Population } \\
\text { studied }\end{array}$ & $\begin{array}{l}\text { Type of reduced } \\
\text { risk with wine }\end{array}$ & $\begin{array}{l}\text { Amount of } \\
\text { wine } \\
\text { associated } \\
\text { with reduced } \\
\text { risk }\end{array}$ & $\begin{array}{c}\text { Beverage } \\
\text { differentiation } \\
\text { observed }\end{array}$ & $\begin{array}{c}\text { Gender } \\
\text { differentiation } \\
\text { observed }\end{array}$ \\
\hline $\begin{array}{l}\text { Harjutsalo et al. } \\
2013 \text { [105] }\end{array}$ & $\begin{array}{c}\text { Finnish } \\
\text { Nephropathy } \\
\text { Study } \\
\text { (FinnDiane) }\end{array}$ & $\begin{array}{l}\text { 3608 T1DM } \\
\text { subjects }\end{array}$ & $\begin{array}{l}\text { Yes for } \\
\text { nephropathy and } \\
\text { retinopathy } \\
\text { microvascular } \\
\text { complications } \\
\text { compared to } \\
\text { spirit drinkers }\end{array}$ & light & Wine<spirits & no \\
\hline $\begin{array}{l}\text { Beulens et al. } \\
2010 \text { [48] }\end{array}$ & $\begin{array}{l}\text { SMART disease } \\
\text { study } \\
\text { The Netherlands }\end{array}$ & $\begin{array}{l}5447 \text { subjects } \\
\text { with DM or } \\
\text { vascular } \\
\text { disease followed } \\
\text { for } 4.7 \mathrm{yr}\end{array}$ & $\begin{array}{l}\text { Yes for stroke, } \\
\text { amputations, } \\
\text { vascular all- } \\
\text { cause mortality }\end{array}$ & 1-2 drinks/day & $\begin{array}{l}\text { Wine }>\text { beer } \\
\text { spirits }\end{array}$ & no \\
\hline $\begin{array}{l}\text { Beulens et al. } \\
2008 \text { [47] }\end{array}$ & $\begin{array}{c}\text { EURODIAB } \\
\text { study } \\
\text { The Netherlands }\end{array}$ & $\begin{array}{l}\text { 3,250 T2DM } \\
\text { subjects }\end{array}$ & $\begin{array}{c}\text { Yes for all } \\
\text { microvascular } \\
\text { complications }\end{array}$ & moderate & Wine>beer, spirits & no \\
\hline $\begin{array}{c}\text { Koppes et al. } 2006 \\
\text { [24] }\end{array}$ & Meta-analysis & T2DM & $\begin{array}{l}\text { Yes for coronary } \\
\text { heart disease } \\
\text { and all-cause } \\
\text { mortality }\end{array}$ & $\begin{array}{l}\text { Light to } \\
\text { moderate }\end{array}$ & no & no \\
\hline
\end{tabular}

The WHO's Global Status Report on Alcohol and Health - 2014 edition clearly states that for diabetes mellitus "a dual relationship exists, whereby a low-risk pattern of drinking may be beneficial while heavy drinking is detrimental". It also states that "for diabetes mellitus, the alcohol attributable fraction (AAF) was negative, meaning that, overall, alcohol consumption exerts a beneficial effect on this disease".

There are, however, specific areas of research that warrant further study as only approximately 30 to 50 percent of wine's protective effects on diabetes can be linked to the biomarkers studied to date, such as its overall effect on insulin sensitivity. Studies could be conducted to examine how wine consumption modifies the risk of type 2 diabetes mellitus based on lifestyle characteristics, such as diet, exercise and body mass index. Components of a healthy lifestyle include maintaining a normal body weight [16], being physically active [99], refraining from smoking [100] and eating a healthy diet [101]. Although several studies have shown that type 2 diabetes can largely be prevented through a healthy lifestyle [16,102], in individuals already at lower risk of type 2 diabetes on the basis of multiple low-risk lifestyle behaviors, moderate alcohol consumption has been associated with an approximately $40 \%$ lower risk compared with abstention [103]. The association between moderate wine consumption and different dietary patterns, such as high versus low glycaemic loads, also requires further study. In addition, information on alcohol metabolising and diabetes-related genes could also be utilised in examinations of interactions between wine, genetic predisposition and diabetes risk [104]. For example, the ADH1C genotype modifies the association between alcohol consumption and diabetes as the $\mathrm{ADH} 1 \mathrm{C}^{\star} 2$ allele, which is related to a slower rate of alcohol metabolism, attenuates the lower diabetes risk among moderate to heavy alcohol consumers. This observation suggests that the association between alcohol consumption and diabetes may be causal but may also be mediated by metabolites such as acetate rather than alcohol itself. In addition, studies on any interactions between the alcohol and phenolic content of wine should be undertaken to tease out the different mechanism of the alcoholic beverages on reducing the risk of type 2 diabetes mellitus.

\section{FUNDING}

The preparation of this manuscript was supported in part by a grant from the National Wine Foundation.

\section{CONFLICT OF INTEREST}

There are no conflicts of interest.

\section{REFERENCES}

[1] Magliano DJ, Peeters A, Vos T, et al. Projecting the burden of diabetes in Australia: What is the size of the matter? Aust New Zealand J Public Health 2009; 33: 540-3. http://dx.doi.org/10.1111/j.1753-6405.2009.00450.x 
[2] Feener EP, King GL. Endothelial dysfunction in diabetes mellitus: role in cardiovascular disease. Heart Fail Monit 2001; 1:74-82.

[3] Gu W, Pagel PS, Warltier DC, Kersten JR. Modifying cardiovascular risk in diabetes mellitus. Anesthesiology 2003; 98: 774-49.

http://dx.doi.org/10.1097/00000542-200303000-00029

[4] Mooradian AD. Cardiovascular disease in type 2 diabetes mellitus: current management guidelines. Arch Intern Med 2003; 163: 33-40.

http://dx.doi.org/10.1001/archinte.163.1.33

[5] Nilsson PM, Gudbjornsdottir S, Eliasson B, Cederholm J. Hypertension in diabetes: trends in clinical control in repeated large-scale national surveys from Sweden. J Hum Hypertens 2003; 17: 37-44. http://dx.doi.org/10.1038/sj.jhh.1001503

[6] Vijan S, Hayward RA. Treatment of hypertension in type 2 diabetes mellitus: blood pressure goals, choice of agents, and setting priorities in diabetes care. Ann Intern Med 2003; 138: 593-602. http://dx.doi.org/10.7326/0003-4819-138-7-200304010$\underline{00018}$

[7] Dunstan D, Zimmet P, Welborn T, Sicree R, Armstrong T, Atkins R, Cameron A, Shaw J, Chadban S. Diabesity and associated disorders in Australia - 2000: the accelerating epidemic. The Australian Diabetes, Obesity and Lifestyle Study (AusDiab). Melbourne: International Diabetes Institute; 2001. [cited December 2014]: Available from http://www.diabetes. com.au/pdf/AusDiab_Report.pdf.

[8] Lindström J, Peltonen M, Eriksson JG, et al. High-fibre, lowfat diet predicts long-term weight loss and decreased type 2 diabetes risk: the Finnish Diabetes Prevention Study. Diabetologia 2006; 49: 912-20. http://dx.doi.org/10.1007/s00125-006-0198-3

[9] Lindström J, Ilanne-Parikka P, Peltonen M, et al. Sustained reduction in the incidence of type 2 diabetes by lifestyle intervention: follow-up of the Finnish Diabetes Prevention Study. Lancet 2006; 368: 1673-9.

http://dx.doi.org/10.1016/S0140-6736(06)69701-8

[10] Alberti KGMM, Zimmet P, Shaw J. International Diabetes Federation: a consensus on Type 2 diabetes prevention, Diabetic Med 2007; 24: 451-63.

http://dx.doi.org/10.1111/j.1464-5491.2007.02157.x

[11] Laatikainen T, Dunbar JA, Chapman A, et al. Prevention of type 2 diabetes by lifestyle intervention in an Australian primary health care setting: Greater Green Triangle (GGT) Diabetes Prevention Project. BMC Public Health 2007; 7: 249.

http://dx.doi.org/10.1186/1471-2458-7-249

[12] Stampfer MJ, Colditz GA, Willett WC, et al. A prospective study of moderate alcohol drinking and risk of diabetes in women. Am J Epidemiol. 1988; 128: 549-58.

[13] Lazarus R, Sparrow D, Weiss ST. Alcohol intake and insulin levels. The Normative Aging Study. Am J Epidemiol 1997; 145: 909-16.

http://dx.doi.org/10.1093/oxfordjournals.aje.a009050

[14] Carlsson S, Hammar N, Efendic S, Persson PG, Ostenson CG, Grill V. Alcohol consumption, Type 2 diabetes mellitus and impaired glucose tolerance in middle-aged Swedish men. Diabet Med 2000; 17: 776-81.

http://dx.doi.org/10.1046/j.1464-5491.2000.00387.x

[15] Conigrave KM, Hu BF, Camargo CA Jr, Stampfer MJ, Willett WC, Rimm EB. A prospective study of drinking patterns in relation to risk of type 2 diabetes among men. Diabetes 2001; 50(10): 2390-5.

http://dx.doi.org/10.2337/diabetes.50.10.2390

[16] Hu FB, Manson JE, Stampfer MJ et al. Diet, lifestyle, and the risk of type 2 diabetes mellitus in women. $\mathrm{N}$ Engl $\mathrm{J}$ Med 2001; 345: 790-97.

http://dx.doi.org/10.1056/NEJMoa010492
[17] Kao WH, Puddey IB, Boland LL, Watson RL, Brancati FL. Alcohol consumption and the risk of type 2 diabetes mellitus: atherosclerosis risk in communities study. Am J Epidemiol 2001; 154: 748-57.

http://dx.doi.org/10.1093/aje/154.8.748

[18] de Vegt F, Dekker JM, Groeneveld WJ et al. Moderate alcohol consumption is associated with lower risk for incident diabetes and mortality: the Hoorn Study. Diabetes Res Clin Pract 2002; 57: 53-56

http://dx.doi.org/10.1016/S0168-8227(02)00013-X

[19] Wannamethee SG, Shaper AG, Perry IJ, Alberti KG. Alcohol consumption and the incidence of type II diabetes. J Epidemiol Community Health 2002; 56: 542-48. http://dx.doi.org/10.1136/jech.56.7.542

[20] Nakanishi N, Suzuki K, Tatara K. Alcohol consumption and risk for development of impaired fasting glucose or type 2 diabetes in middle-aged Japanese men. Diabetes Care 2003; 26: 48-54.

http://dx.doi.org/10.2337/diacare.26.1.48

[21] Wannamethee SG, Camargo CA Jr, Manson JE, Willett WC, Rimm EB. Alcohol Drinking Patterns and Risk of Type 2 Diabetes Mellitus Among Younger Women. Arch Intern Med 2003; 163: 1329-36.

http://dx.doi.org/10.1001/archinte.163.11.1329

[22] Howard AA, Arnsten JH, Gourevitch MN. Effect of alcohol consumption on diabetes mellitus: a systematic review. Ann Intern Med 2004; 140: 211-9.

http://dx.doi.org/10.7326/0003-4819-140-6-200403160$\underline{00011}$

[23] Carlsson S, Hammar N, Grill V. Alcohol consumption and type 2 diabetes. Meta-analysis of epidemiological studies indicates a U-shaped relationship. Diabetologia 2005; 48: 1051-4. http://dx.doi.org/10.1007/s00125-005-1768-5

[24] Koppes LL, Dekker JM, Hendriks HF, Bouter LM, Heine RJ. Moderate alcohol consumption lowers the risk of type 2 diabetes: a meta-analysis of prospective observational studies. Diabetes Care 2005; 28: 719-25. http://dx.doi.org/10.2337/diacare.28.3.719

[25] Baliunas DO, Taylor BJ, Irving $H$, Roerecke M, Patra J, Mohapatra S, Rehm J. Alcohol as a risk factor for type 2 diabetes: A systematic review and meta-analysis. Diabetes Care. 2009; 32: 2123-32. http://dx.doi.org/10.2337/dc09-0227

[26] Pietraszek A, Gregersen S, Hermansen K. Alcohol and type 2 diabetes. A review. Nutr Metab Cardiovasc Dis 2010; 20:366-75. http://dx.doi.org/10.1016/j.numecd.2010.05.001

[27] Ajani UA, Gaziano JM, Lotufo PA, Liu S, Hennekens $\mathrm{CH}$ Buring JE, Manson JE. Alcohol consumption and risk of coronary heart disease by diabetes status. Circulation 2000 102: $500-5$. http://dx.doi.org/10.1161/01.CIR.102.5.500

[28] Scognamiglio R, Avogaro A, Negut C, Piccolotto R, Vigili de Kreutzenberg S, Tiengo A. Early myocardial dysfunction in the diabetic heart: current research and clinical applications. Am J Cardiol 2004; 93: 17A-20A. http://dx.doi.org/10.1016/j.amjcard.2003.11.004

[29] Rasouli B, Ahlbom A, Andersson T, Grill V, Midthjell K, Olsson L, Carlsson S. Alcohol consumption is associated with reduced risk of Type 2 diabetes and autoimmune diabetes in adults: results from the Nord-Trøndelag health study. Diabet Med 2013; 30: 56-64. http://dx.doi.org/10.1111/j.1464-5491.2012.03713.x

[30] Beulens JW, Stolk RP, van der Schouw YT, Grobbee DE, Hendriks HF, Bots ML. Alcohol consumption and risk of type 2 diabetes among older women. Diabetes Care 2005; 28: 2933-8.

http://dx.doi.org/10.2337/diacare.28.12.2933 
[31] Lapidus L, Bengtsson C, Bergfors E, Björkelund C, Spak F, Lissner L. Alcohol intake among women and its relationship to diabetes incidence and all-cause mortality: the 32-year follow-up of a population study of women in Gothenburg, Sweden. Diabetes Care 2005; 28: 2230-5. http://dx.doi.org/10.2337/diacare.28.9.2230

[32] Fagherazzi G, Vilier A, Lajous M, Boutron-Ruault MC, Balkau B, Clavel-Chapelon F, Bonnet F. Wine consumption throughout life is inversely associated with type 2 diabetes risk, but only in overweight individuals: results from a large female French cohort study. Eur J Epidemiol 2014; 29: 8319.

http://dx.doi.org/10.1007/s10654-014-9955-7

[33] Beulens JW, van der Schouw YT, Bergmann MM, et al. Alcohol consumption and risk of type 2 diabetes in European men and women: influence of beverage type and body size The EPIC-InterAct study. J Intern Med 2012; 272: 358-70. http://dx.doi.org/10.1111/j.1365-2796.2012.02532.x

[34] National Health and Medical Research Council, Australian guidelines to reduce health risks from drinking alcohol (March 2009). [Assessed December 2014]. Available: http://www.nhmrc.gov.au/ publications/synopses/ds10syn.htm

[35] Bauer F, Beulens JW, van der A DL, et al. Dietary patterns and the risk of type 2 diabetes in overweight and obese individuals. Eur J Nutr 2013; 52: 1127-34. http://dx.doi.org/10.1007/s00394-012-0423-4

[36] Fernemark $H$, Jaredsson C, Bunjaku B, Rosenqvist U, Nystrom $\mathrm{FH}$, Guldbrand $\mathrm{H}$. A randomized cross-over trial of the postprandial effects of three different diets in patients with type 2 diabetes. PLoS One 2013; 8: e79324. http://dx.doi.org/10.1371/journal.pone.0079324

[37] Koloverou E, Panagiotakos DB, Pitsavos C, et al. Effects of alcohol consumption and the metabolic syndrome on 10-year incidence of diabetes: The ATTICA study. Diabetes Metab 2015; 41: 152-9.

http://dx.doi.org/10.1016/j.diabet.2014.06.003

[38] Hodge AM, English DR, O'Dea K, Giles GG. Alcohol intake, consumption pattern and beverage type, and the risk of Type 2 diabetes. Diabet Med 2006; 23: 690-7. http://dx.doi.org/10.1111/j.1464-5491.2006.01864.x

[39] Djoussé L, Biggs ML, Mukamal KJ, Siscovick DS. Alcohol consumption and type 2 diabetes among older adults: the Cardiovascular Health Study. Obesity (Silver Spring) 2007; 15: $1758-65$.

http://dx.doi.org/10.1038/oby.2007.209

[40] Gérard MJ, Klatsky AL, Siegelaub AB, Friedman GD, Feldman R. Serum glucose levels and alcohol-consumption habits in a large population. Diabetes 1977; $26: 780-5$. http://dx.doi.org/10.2337/diab.26.8.780

[41] Wannamethee SG, Shaper AG. Alcohol, body weight, and weight gain in middle-aged men. Am J Clin Nutr 2003; 77: 1312-7.

[42] Wannamethee SG, Lowe GD, Shaper G, et al. The effects of different alcoholic drinks on lipids, insulin and haemostatic and inflammatory markers in older men. Thromb Haemost 2003; 90: 1080-7.

http://dx.doi.org/10.1160/th03-04-0221

[43] Gin H, Rigalleau V, Caubet O, Masquelier J, Aubertin J. Effects of red wine, tannic acid, or ethanol on glucose tolerance in non-insulin-dependent diabetic patients and on starch digestibility in vitro. Metabolism 1999; 48: 1179-83. http://dx.doi.org/10.1016/S0026-0495(99)90135-X

[44] Cullmann M, Hilding A, Östenson CG. Alcohol consumption and risk of pre-diabetes and type 2 diabetes development in a Swedish population. Diabet Med 2012; 29: 441-52. http://dx.doi.org/10.1111/j.1464-5491.2011.03450.x

[45] Ceriello A, Bortolotti N, Motz E. et al. Red wine protects diabetic patients from meal-induced oxidative stress and thrombosis activation: a pleasant approach to the prevention of cardiovascular disease in diabetes. Eur J Clin Invest 2001; 31: $322-28$

http://dx.doi.org/10.1046/j.1365-2362.2001.00818.x

[46] Marfella R, Cacciapuoti $F$, Siniscalchi $M$, et al. Effect of moderate red wine intake on cardiac prognosis after recent acute myocardial infarction of subjects with Type 2 diabetes mellitus. Diabet Med 2006; 23: 974-81.

http://dx.doi.org/10.1111/j.1464-5491.2006.01886.x

[47] Beulens JW, Rimm EB, Hu FB, Hendriks HF, Mukamal KJ. Alcohol consumption, mediating biomarkers and risk of type 2 diabetes among middle-aged women. Diabetes Care 2008; 31: $2050-5$. http://dx.doi.org/10.2337/dc08-0814

[48] Beulens JW, Algra A, Soedamah-Muthu SS, Visseren FL, Grobbee DE, van der Graaf Y; SMART Study Group. Alcohol consumption and risk of recurrent cardiovascular events and mortality in patients with clinically manifest vascular disease and diabetes mellitus: the Second Manifestations of ARTerial (SMART) disease study. Atherosclerosis. 2010; 212: 281-6. http://dx.doi.org/10.1016/j.atherosclerosis.2010.04.034

[49] Blomster JI, Zoungas S, Chalmers J, et al. The relationship between alcohol consumption and vascular complications and mortality in individuals with type 2 diabetes. Diabetes Care 2014; 37: 1353-9.

http://dx.doi.org/10.2337/dc13-2727

[50] Rojo-Martínez G, Maymó-Masip E, Rodríguez MM, et al. Serum sCD163 levels are associated with type 2 diabetes mellitus and are influenced by coffee and wine consumption: results of the Di@bet.es study. PLoS One 2014; 9:e101250. http://dx.doi.org/10.1371/journal.pone.0101250

[51] Lu B, Solomon DH, Costenbader KH, Keenan BT, Chibnik LB, Karlson EW. Alcohol consumption and markers of inflammation in women with preclinical rheumatoid arthritis. Arthritis Rheum 2010; 62: 3554-9. http://dx.doi.org/10.1002/art.27739

[52] Schubert C, Fuchs D. The relationship between alcohol intake and cellular immune activity in systemic lupus erythematosus may change from inhibitory to stimulatory within 2 months of study: findings from an integrative singlecase study. Clin Rheumatol 2010; 29: 229-30. http://dx.doi.org/10.1007/s10067-009-1309-6

[53] Facchini F, Chen Y, Reaven G. Light-to-moderate alcohol intake is associated with enhanced insulin sensitivity. Diabetes Care 1994; 17: 115-9.

http://dx.doi.org/10.2337/diacare.17.2.115

[54] Davies MJ, Baer DJ, Judd JT, Brown ED, Campbell WS, Taylor PR. Effects of moderate alcohol intake on fasting insulin and glucose concentrations and insulin sensitivity in postmenopausal women: a randomized controlled trial. JAMA 2002; 287: 2559-62.

http://dx.doi.org/10.1001/jama.287.19.2559

[55] Goude D, Fagerberg B, Hulthe J. Alcohol consumption, the metabolic syndrome and insulin resistance in 58-year-old clinically healthy men (AIR study). Clin Sci (Lond) 2002; 102: 345-52.

\section{http://dx.doi.org/10.1042/cs1020345}

[56] Beulens JW, Patel A, Vingerling JR, et al. Effects of blood pressure lowering and intensive glucose control on the incidence and progression of retinopathy in patients with type 2 diabetes mellitus: a randomised controlled trial. Diabetologia 2009; 52: 2027-36. http://dx.doi.org/10.1007/s00125-009-1457-x

[57] Joosten MM, Beulens JW, Kersten S, Hendriks HF. Moderate alcohol consumption increases insulin sensitivity and ADIPOQ expression in postmenopausal women: a randomised, crossover trial. Diabetologia 2008; 51: 1375-81. http://dx.doi.org/10.1007/s00125-008-1031-y

[58] Siler S, Neese R, Christiansen M, Hellerstein M. The inhibition of gluconeogenesis following alcohol in humans. Am J Physiol Endocrinol Metab 1998; 275: E897-907. 
[59] Brand-Miller JC, Fatema K, Middlemiss C, Bare M, Liu V, Atkinson F, Petocz P. Effect of alcoholic beverages on postprandial glycemia and insulinemia in lean, young, healthy adults. Am J Clin Nutr. 2007;85(6):1545-51. Erratum in: Am J Clin Nutr 2007; 86: 808.

[60] Sierksma A, Patel H, Ouchi N, Kihara S, Funahashi T, Heine RJ, Grobbee DE, Kluft C, Hendriks HF. Effect of moderate alcohol consumption on adiponectin, tumor necrosis factoralpha, and insulin sensitivity. Diabetes Care 2004; 27: 184-9. http://dx.doi.org/10.2337/diacare.27.1.184

[61] Beulens JW, de Zoete EC, Kok FJ, Schaafsma G, Hendriks HF. Effect of moderate alcohol consumption on adipokines and insulin sensitivity in lean and overweight men: a diet intervention study. Eur J Clin Nutr 2007; 62: 1098-105.

http://dx.doi.org/10.1038/sj.ejcn.1602821

[62] Beulens JW, van Loon LJ, Kok FJ, et al. The effect of moderate alcohol consumption on adiponectin oligomers and muscle oxidative capacity: a human intervention study. Diabetologia 2007; 50: 1388-92. http://dx.doi.org/10.1007/s00125-007-0699-8

[63] Imhof A, Plamper I, Maier S, Trischler G, Koenig W. Effect of drinking on adiponectin in healthy men and women: a randomized intervention study of water, ethanol, red wine, and beer with or without alcohol. Diabetes Care 2009; 32: 1101-3.

http://dx.doi.org/10.2337/dc08-1723

[64] Li S, Shin HJ, Ding EL, van Dam RM. Adiponectin levels and risk of type 2 diabetes: a systematic review and metaanalysis. JAMA 2009; 302: 179-88.

http://dx.doi.org/10.1001/jama.2009.976

[65] Avogaro A, Watanabe RM, Gottardo L, de Kreutzenberg S, Tiengo A, Pacini G. Glucose tolerance during moderate alcohol intake: insights on insulin action from glucose/lactate dynamics. J Clin Endocrinol Metab 2002; 87: 1233-38. http://dx.doi.org/10.1210/jcem.87.3.8347

[66] Kiechl S, Willeit J, Poewe W, Egger G, Oberhollenzer F, Muggeo M, Bonora E. Insulin sensitivity and regular alcohol consumption: large, prospective, cross sectional population study (Bruneck study). BMJ 1996; 313: 1040-4.

http://dx.doi.org/10.1136/bmj.313.7064.1040

[67] Mayer EJ, Newman B, Quesenberry CP Jr, Friedman GD, Selby JV. Alcohol consumption and insulin concentrations. Role of insulin in associations of alcohol intake with highdensity lipoprotein cholesterol and triglycerides. Circulation 1993; 88(5 Pt 1): 2190-7.

http://dx.doi.org/10.1161/01.CIR.88.5.2190

[68] Napoli R, Cozzolino D, Guardasole V, et al. Red wine consumption improves insulin resistance but not endothelial function in type 2 diabetic patients. Metabolism 2005; 54(3): 306-13.

http://dx.doi.org/10.1016/j.metabol.2004.09.010

[69] Davies MJ. Insulin secretagogues. Curr Med Res Opin 2002; 18(suppl 1): s22-30.

http://dx.doi.org/10.1185/030079902125000200

[70] Ajani UA, Hennekens CH, Spelsberg A, Manson JE. Alcohol consumption and risk of type 2 diabetes mellitus among US male physicians. Arch Intern Med 2000; 160: 1025-30. http://dx.doi.org/10.1001/archinte.160.7.1025

[71] Solomon CG, Hu FB, Stampfer MJ et al. Moderate alcohol consumption and risk of coronary heart disease among women with type 2 diabetes mellitus. Circulation 2000; 102: 494-9.

http://dx.doi.org/10.1161/01.CIR.102.5.494

[72] Bantle AE, Thomas W, Bantle JP. Metabolic effects of alcohol in the form of wine in persons with type 2 diabetes mellitus. Metabolism 2008; 57: 241-5. http://dx.doi.org/10.1016/j.metabol.2007.09.007

[73] Shai I, Wainstein J, Harman-Boehm I, et al. Glycemic effects of moderate alcohol intake among patients with type 2 diabetes: a multicenter, randomized, clinical intervention trial. Diabetes Care 2007; 30: 3011-6.

http://dx.doi.org/10.2337/dc07-1103

[74] Aldhahi W, Hamdy O. Adipokines, inflammation, and the endothelium in diabetes. Curr Diab Rep 2003; 3: 293-8.

\section{http://dx.doi.org/10.1007/s11892-003-0020-2}

[75] Spranger J, Kroke A, Mohlig M, Bergmann MM, Ristow M, Boeing $\mathrm{H}$, Pfeiffer AF. Adiponectin and protection against type 2 diabetes mellitus. Lancet 2003; 361:226-8. http://dx.doi.org/10.1016/S0140-6736(03)12255-6

[76] Duncan BB, Schmidt MI. The epidemiology of low-grade chronic systemic inflammation and type 2 diabetes. Diabetes Technol Ther 2006; 8: 7-17. http://dx.doi.org/10.1089/dia.2006.8.7

[77] Pischon T, Girman CJ, Hotamisligil GS, Rifai N, Hu FB, Rimm EB. Plasma adiponectin levels and risk of myocardial infarction in men. JAMA 2004; 291: 1730-7. http://dx.doi.org/10.1001/jama.291.14.1730

[78] Beulens JW, van Beers RM, Stolk RP, Schaafsma G, Hendriks HF. The effect of moderate alcohol consumption on fat distribution and adipocytokines. Obesity (Silver Spring) 2006; 14: 60-6.

\section{http://dx.doi.org/10.1038/oby.2006.8}

[79] Englund Ogge L, Brohall G, Behre CJ, Schmidt C, Fagerberg B. Alcohol consumption in relation to metabolic regulation, inflammation, and adiponectin in 64-year-old Caucasian women: a population- based study with a focus on impaired glucose regulation. Diabetes Care 2006; 29: 908-13. http://dx.doi.org/10.2337/diacare.29.04.06.dc05-1782

[80] Ouchi N, Kihara S, Funahashi T, et al. Reciprocal association of $\mathrm{C}$-reactive protein with adiponectin in blood stream and adipose tissue. Circulation 2003; 107: 671-4. http://dx.doi.org/10.1161/01.CIR.0000055188.83694.B3

[81] Jenkins DJ, Wolever TM, Taylor RH, et al. Glycemic index of foods: a physiological basis for carbohydrate exchange. Am J Clin Nutr 1981; 34: 362-6.

[82] Villegas R, Liu, S, Gao YT, Yang, G, Li H, Zheng W, Shu XO Prospective Study of Dietary Carbohydrates, Glycemic Index, Glycemic Load, and Incidence of Type 2 Diabetes Mellitus in Middle-aged Chinese Women. Arch Intern Med 2007; 6167: 2310-6. http://dx.doi.org/10.1001/archinte.167.21.2310

[83] Mekary RA, Rimm EB, Giovannucci E, et al. Joint association of glycemic load and alcohol intake with type 2 diabetes incidence in women. Am J Clin Nutr 2011; 94: 1525-32. http://dx.doi.org/10.3945/ajcn.111.023754

[84] van de Wiel A. Diabetes mellitus and alcohol. Diabetes Metab Res Rev 2004; 20: 263-7.

http://dx.doi.org/10.1002/dmrr.492

[85] Avogaro A, Valerio A, Miola M, Crepaldi C, Pavan P, Tiengo $A$, del Prato $S$. Ethanol impairs insulin-mediated glucose uptake by an indirect mechanism. J Clin Endocrinol Metab 1996; 81: 2285-90.

[86] Flanagan D, Wood P, Sherwin R, Debrah K, Kerr D. Gin and tonic and reactive hypoglycemia: what is important-the gin, the tonic, or both? J Clin Endocrinol Metab 1998; 83: 796800.

[87] Ceriello A, Bortolotti N, Motz E. et al. Meal-induced oxidative stress and low-density lipoprotein oxidation in diabetes: the possible role of hyperglycemia. Metabolism 1999; 48: 15038. http://dx.doi.org/10.1016/S0026-0495(99)90237-8

[88] Diwadkar VA, Anderson JW, Bridges SR, Gowri MS, Oelgten PR. Postprandial low-density lipoproteins in type 2 diabetes are oxidized more extensively than fasting diabetes and control samples. Proc Soc Exp Biol Med 1999; 222: 178-84 http://dx.doi.org/10.1046/j.1525-1373.1999.d01-129.x

[89] Ceriello A, Bortolotti N, Motz E. et al. Meal-generated oxidative stress in diabetes. The protective effect of red wine. 
Diabetes Care 1999; 22: 2084-5.

http://dx.doi.org/10.2337/diacare.22.12.2084

[90] Ceriello A, Taboga C, Tonutti L, Giacomello R, Stel L, Motz E, Pirisi M. Post-meal coagulation activation in diabetes mellitus: the effect of acarbose. Diabetologia 1996; 39: 46973.

http://dx.doi.org/10.1007/BF00400679

[91] Landrault N, Poucheret P, Azay J, Krosniak M, Gasc F, Jenin C, Cros G, Teissedre PL. Effect of a polyphenols-enriched chardonnay white wine in diabetic rats. J Agric Food Chem 2003; 51: 311-8.

http://dx.doi.org/10.1021/jf020219s

[92] Nyström T, Nygren A, Sjöholm A. Increased levels of tumour necrosis factor-alpha (TNF-alpha) in patients with Type II diabetes mellitus after myocardial infarction are related to endothelial dysfunction. Clin Sci (Lond) 2006; 110: 673-81. http://dx.doi.org/10.1042/CS20050353

[93] Martinez J, Moreno JJ. Effect of resveratrol, a natural polyphenolic compound, on reactive oxygen species and prostaglandin production. Biochem Pharmacol 2000; 59: 865-70.

http://dx.doi.org/10.1016/S0006-2952(99)00380-9

[94] Stratton IM, Adler Al, Neil HA, et al. Association of glycaemia with macrovascular and microvascular complications of type 2 diabetes (UKPDS 35): prospective observational study. BMJ. 2000; 321: 405-12. http://dx.doi.org/10.1136/bmj.321.7258.405

[95] Ritz E, Orth SR. Nephropathy in patients with type 2 diabetes mellitus. N Engl J Med 1999; 34: 1127-33. http://dx.doi.org/10.1056/NEJM199910073411506

[96] Adler Al, Stevens RJ, Manley SE, Bilous RW, Cull CA, Holman RR; UKPDS GROUP. Development and progression of nephropathy in type 2 diabetes: the United Kingdom Prospective Diabetes Study (UKPDS 64). Kidney Int 2003; 63: 225-32.

http://dx.doi.org/10.1046/j.1523-1755.2003.00712.x

[97] Ravid M, Brosh D, Ravid-Safran D, Levy Z, Rachmani R. Main risk factors for nephropathy in type 2 diabetes mellitus are plasma cholesterol levels, mean blood pressure, and hyperglycemia. Arch Intern Med 1998; 158: 998-1004. http://dx.doi.org/10.1001/archinte.158.9.998

[98] World Health Organization. Global Status Report on Alcohol and Health-2014 edition. WHO. Geneva, 2014.

[99] Wannamethee SG, Shaper AG, Alberti KG. Physical activity, metabolic factors, and the incidence of coronary heart disease and type 2 diabetes. Arch Intern Med 2000; 160: 2108-16.

http://dx.doi.org/10.1001/archinte.160.14.2108
[100] Rimm EB, Manson JE, Stampfer MJ, et al. Cigarette smoking and the risk of diabetes in women. Am J Public Health 1993; 83: $211-4$ http://dx.doi.org/10.2105/AJPH.83.2.211

[101] Liese AD, Nichols M, Sun X, D’Agostino RB Jr, Haffner SM Adherence to the DASH Diet is inversely associated with incidence of type 2 diabetes: the insulin resistance atherosclerosis study. Diabetes Care 2009; 32: 1434-6. http://dx.doi.org/10.2337/dc09-0228

[102] Mozaffarian D, Kamineni A, Carnethon M, Djousse L, Mukamal KJ, Siscovick D. Lifestyle risk factors and newonset diabetes mellitus in older adults: the cardiovascular health study. Arch Intern Med 2009; 169: 798-807. http://dx.doi.org/10.1001/archinternmed.2009.21

[103] Joosten MM, Grobbee DE, van der A DL, Verschuren WM, Hendriks HF, Beulens JW. Combined effect of alcohol consumption and lifestyle behaviors on risk of type 2 diabetes. Am J Clin Nutr 2010; 91: 1777-83. http://dx.doi.org/10.3945/ajcn.2010.29170

[104] Beulens JW, Rimm EB, Hendriks HF, et al. Alcohol consumption and type 2 diabetes: influence of genetic variation in alcohol dehydrogenase. Diabetes 2007; 56: 2388-94.

http://dx.doi.org/10.2337/db07-0181

[105] Harjutsalo V, Feodoroff M, Forsblom C, Groop PH, FinnDiane Study Group. Patients with Type 1 diabetes consuming alcoholic spirits have an increased risk of microvascular complications. Diabet Med 2014; 31: 156-64. http://dx.doi.org/10.1111/dme.12307

[106] Athyros VG, Liberopoulos EN, Mikhailidis DP, et al. Association of drinking pattern and alcohol beverage type with the prevalence of metabolic syndrome, diabetes, coronary heart disease, stroke, and peripheral arterial disease in a Mediterranean cohort. Angiology 2007; 58: 68997. http://dx.doi.org/10.1177/0003319707306146

[107] Lim SS, Vos T, Flaxman AD, Danaei G, et al. A comparative risk assessment of burden of disease and injury attributable to 67 risk factors and risk factor clusters in 21 regions, 19902010: a systematic analysis for the Global Burden of Disease Study 2010. Lancet 2012; 380: 2224-60. http://dx.doi.org/10.1016/S0140-6736(12)61766-8

[108] Marques-Vidal P, Vollenweider P, Waeber G. Alcohol consumption and incidence of type 2 diabetes. Results from the CoLaus study. Nutr Metab Cardiovasc Dis 2015; 25: 7584

http://dx.doi.org/10.1016/j.numecd.2014.08.010 